\title{
Bone mineral density in Iranian patients: Effects of age, sex, and body mass index
}

\author{
Mehrdad Aghaei ${ }^{1}$, Hamid Reza Bazr Afshan ${ }^{1 \star}$, Mostafa Qorbani $^{2}$, Hossien Shadpour Dashti ${ }^{3}$, \\ Roya Safari ${ }^{4}$ \\ ${ }^{1}$ Bone joints \& Connective Tissue Disease Research Center, Golestan University of Medical Sciences, Gorgan, Iran; \\ *Corresponding Author: Mahdieh.shojaa mw@yahoo.com \\ ${ }^{2}$ Department of Epidemiology \& Biostatistics, School of Public Health, Tehran University of Medical Sciences, Tehran, Iran \\ ${ }^{3}$ Department of Internal Medicine, Golestan University of Medical Sciences, Gorgan, Iran \\ ${ }^{4}$ Department of Internal Medicine, Tehran University of Medical Sciences, Tehran, Iran
}

Received 22 June 2012; revised 28 July 2012; accepted 5 August 2012

\section{ABSTRACT}

Introduction: Osteoporosis is a multifactorial skeletal disease that is characterized by reduced bone mineral density (BMD). BMD values depend on several factors such as age, sex and age at menopause. The purpose of this study was to determine the prevalence and changes in bone mineral density in Iranian patients. Methods: Three hundred patients were selected through random sampling technique in 2009. BMD was assessed by Norland (Excell) technique at the lumbar and femoral neck. Weight and height were measured through standard methods. A thorough history was taken from each patient. The data was analyzed using SPSS software version 13.0. P-values less than 0.05 were considered statistically significant. Results: From among the 300 studied patients, $86.6 \%$ were female. their mean age was 52.7 years. Their average body mass index (BMI) was $28.14 \mathrm{~kg} / \mathrm{m}^{2}$. Mean T-Score at lumbar spine and femoral neck was $-1.07 \pm 1.19$ and $-1.75 \pm 1.33$ respectively. Mean BMD value at lumbar spine and femoral neck was $0.92 \pm 0.19$ and $0.77 \pm 0.16$ respectively. The prevalence of osteoporosis at lumbar spine and femoral neck was $33.7 \%$ and 16.7 , respectively. There was a significant correlation between age, BMI and BMD values ( $P$-Value $<0.01$ ). Correlation between gender and BMD value at the lumbar spine and femoral neck was not significant. Conclusion: This study shows that ageing and low BMI are risk factors associated with bone loss. it is recommended to measure BMD and implement prevention programs for highrisk people.

Keywords: Bone Mineral Density; Body Mass Index; Age; Gender

\section{INTRODUCTION}

Osteoporosis is a multifactorial skeletal disease characterized by reduced bone mineral density (BMD) along with the deterioration of the microarchitectural structure of bone tissue, and a consequent increase in bone fragility and fracture risk $[1,2]$. Osteoporosis is a common disease among the elderly, particularly the post-menopausal women [3-7]. BMD values depend on such factors as age, sex and age at menopause [8-10]. It has been predicted that in $2050,50 \%$ of all hip fractures in the world will be occurring in Asia [11]. Osteoporosis is a disease that affects many millions of people around the world. It affects more than 75 million people in the United States, Europe and Japan [12]. It is estimated that world's annual incidence of hip fracture will increase from 1.26 million cases in 1990 to 2.6 million by 2025 and to 4.5 million by 2050 [13]. Osteoporotic fractures affect the quality of life and are associated with premature mortality [14].

The prevalence of osteoporosis among Iranian women varies from 6 to 34.4 percent in different cities and provinces [15-18]. In the present study, we evaluated the prevalence and correlation of osteoporosis with demographic factors among patients referred to a densitometry center in Gorgan, a city located in North Iran.

\section{MATERIAL \& METHODS}

From among 3000 patients who were referred to the Azar 5th teaching hospital affiliated to Gorgan University of Medical Sciences, 300 patients were selected through random sampling technique in 2009. The individuals with underlying diseases affecting bone mass such as rheumatoid arthritis, renal and liver failure and any cansers were excluded. BMD was assessed by Norland (Excell) technique at the lumbar and femoral neck. Based on WHO classification, individuals with T-score 
values higher than -1 were classified as normal, those with $\mathrm{T}$-score between -1 and -2.5 as osteopenic, and those with $\mathrm{T}$-score less than -2.5 as osteoporotic [12]. Weight and height were measured through standard methods and BMI was calculated by dividing weight (kilogram) by square height (square meter). A thorough history was taken from each patient. The data was analyzed using SPSS software version 13.0. The descriptive data were presented as frequency, mean and SD, whereas regression, $\times 2$ and $\mathrm{T}$-test were used for further analysis and the comparison of the data. P-values less than 0.05 were considered statistically significant.

\section{RESULTS}

From among the 300 studied patients, 260 (86.6\%) were female. Their mean age was $52.7 \pm 14.42$ years, ranging from 21 to 85 years. Their body mass index (BMI) ranged from 16.0 to $45.54 \mathrm{~kg} / \mathrm{m}^{2}$, with an average of $28.14(\mathrm{SD}=5.42)$. Mean $\mathrm{BMD}$ value at the lumbar spine and femoral neck was $0.92 \pm 0.19$ and $0.77 \pm 0.16$ respectively. According to the $\mathrm{T}$ Score values at lumbar spine, 101 patients (33.7\%) had osteoporosis and 115 $(38.3 \%)$ had osteopenia. Furthermore, regarding the values reported at the femoral neck, 50 patients $(16.7 \%)$ had osteoporosis and 121 others (40.3\%) had osteopenia. Mean T-Score at lumbar spine and femoral neck was $-1.07 \pm 1.19(-3.78$ to 2.25$)$ and $-1.75 \pm 1.33(-5.07$ to $1.75)$, respectively. There was a positive and significant correlation between age and BMD values at both lumbar spine $(\mathrm{r}=0.32, \mathrm{P}-$ Value $<0.01)$ and femoral neck $(\mathrm{r}=$ 0.42 , P-Value $<0.01)$. There was a significant and positive correlation between BMI values and bone loss at lumbar spine $(\mathrm{r}=0.31$, P-Value $<0.01)$; such a significant correlation, however, was not reported at the femoral neck region $(\mathrm{r}=0.12, \mathrm{P}-\mathrm{Value}=0.11)$. The prevalence of osteoporosis among women and men at the lumbar spine was 14 and 2.7 percent respectively. 28.3 percent of women and 5.3 percent of men had osteoporosis at the femoral neck but correlation between gender and BMD value at the lumbar spine and femoral neck was not significant (Table 1). The correlation between age groups and BMD at both lumbar spine and femoral neck was significant $(\mathrm{P}-\mathrm{Value}<0.01)$ (Table 2$)$.

\section{DISCUSSION}

In our study, the prevalence of osteoporosis at lumbar spine and femoral neck was 33.7 and 16.7 respectively. Table 3 shows the prevalence of osteoporosis at the LS and $\mathrm{FN}$ in different places of the world. The figure ranges from 6.3 in Saudi Arabia to 40.1 percent Korea that is consistent with this study. These discrepancies can be explained based on the differences in race, life style and dietary habits of the people of these countries. In
Table 1. Correlation between BMD and sex.

\begin{tabular}{ccccc}
\hline Site & BMD status & $\begin{array}{c}\text { Women } \\
\text { number } \\
(\%)\end{array}$ & $\begin{array}{c}\text { Men } \\
\text { number } \\
(\%)\end{array}$ & p-value \\
\hline $\begin{array}{c}\text { Lumbar } \\
\text { spine }\end{array}$ & Osteoporosis & $42(14)$ & $8(2.7)$ & \\
& Osteopeni & $105(35)$ & $16(5.3)$ & 0.81 \\
& normal & $113(37.7)$ & $16(5.3)$ & \\
$\begin{array}{c}\text { Femoral } \\
\text { neck }\end{array}$ & Osteoporosis & $85(28.3)$ & $16(5.3)$ & \\
& normal & $96(32)$ & $19(6.3)$ & 0.06 \\
\hline
\end{tabular}

Table 2. Prevalence of osteoporosis and BMD status according to the age groups at both lumbar spine and femoral neck.

\begin{tabular}{cccc}
\hline $\begin{array}{c}\text { Aged } \\
\text { groups }\end{array}$ & $\begin{array}{c}\text { Osteoporosis } \\
\text { lumbar femur } \\
\text { number (\%) }\end{array}$ & $\begin{array}{c}\text { Osteopeni } \\
\text { lumbar femur } \\
\text { number (\%) }\end{array}$ & $\begin{array}{c}\text { Normal } \\
\text { lumbar femur } \\
\text { number (\%) }\end{array}$ \\
\hline $\begin{array}{c}\text { Less } \\
\text { than 29 }\end{array}$ & $2(10)$ & $5(25)$ & $13(65)$ \\
$30-39$ & $2(10)$ & $9(45)$ & $9(45)$ \\
& $2(7.5)$ & $7(25)$ & $19(67.9)$ \\
$40-49$ & $1(1.7)$ & $13(46.4)$ & $13(46.4)$ \\
& $4(7.6)$ & $14(23.3)$ & $45(75)$ \\
$50-59$ & $15(15.8)$ & $22(36.7)$ & $34(56.7)$ \\
& $31(32.6)$ & $44(46.3)$ & $39(41.1)$ \\
$60-69$ & $17(28.3)$ & $33(55)$ & $10(16.7)$ \\
& $32(53.3)$ & $20(33)$ & $8(13.3)$ \\
More & $13(35.1)$ & $21(56.8)$ & $3(8.1)$ \\
than 70 & $30(81.1)$ & $7(18.9)$ & 0 \\
\hline
\end{tabular}

Table 3. Prevalence of osteoporosis in different places of the world.

\begin{tabular}{ccc}
\hline place & \multicolumn{2}{c}{$\begin{array}{c}\text { Prevalence of osteoporosis femoral neck } \\
\text { lumbar spine }\end{array}$} \\
\hline Japan & 11.6 & 38 \\
Saudi Arabia & 6.3 & 38.3 \\
Canada & 7.9 & 12.1 \\
Thailand & 13.6 & 19.8 \\
Korea & 12.4 & 40.1 \\
Turkey & 7.5 & 33 \\
Iran & 18.9 & 18.9 \\
\hline
\end{tabular}

line with our study, many studies have introduced age as an important factor for bone loss [17-24]. Jang et al. showed that the prevalence of osteoporosis in postmenopausal women increases with age from $30.6 \%$ in those aged between 45 and 64 to 68.7 percent in those 
aged over 75 [25]. In our study, there was a positive strong correlation between BMI and bone mineral density in lumbar spine. In other words, each unit increase in BMI values is associated with 0.314 unit increase in bone density. Several studies in the UAE [26], India [27], Japan [28], Netherlands [29], the US [30] and Morocco [31] have considered a positive correlation between BMI and bone mineral density. A Brazilian study reported that body weight is important for gaining and losing body mass, and causes an impact on BMD-age relationship [32]. Our results showed that the prevalence of osteoporosis among women was more than men but this correlation was not significant. In some study, on the contrary to our findings, revealed significantly higher prevalence of osteoporosis in women than in men [33-36] This can be due to the very low number of men compared with women in our study. On the other hand, although hormonal changes in women, especially after menopause, has an important role in osteoporosis, but men should not ignore about BMD changes.

\section{CONCLUSION}

The present research indicated the negative effect of age and positive effect of BMI on bone mass. Although, the prevalence of osteoporosis was higher among women, there was no statistically significant difference in this regard. As a result, it is recommended to use risk factors for requesting testing, mainly DXA and implement prevention programs for high-risk people and more attention needs to be paid to men osteoporosis. Future prospective studies are therefore necessary to gather more accurate information in this regard.

\section{ACKNOWLEDGEMENTS}

The study was funded by the Department of Research affairs of Golestan University of Medical Sciences. The authors wish to gratefully acknowledge the contribution of all the patients who participated in the study.

\section{REFERENCES}

[1] Ichchou, L., Allali, F., Rostom, S., Bennani, L., Hmamouchi, I., Abourazzak, F.Z., Khazzani, H., El Mansouri, L., Abouqa, R. and Hajjaj-Hassounil, N. (2010) Relationship between spine osteoarthritis, bone mineral density and bone turn over markers in post menopausal women. BMC Women's Health, 10, 2-7.

[2] Raisz, L.G. and Shoukri, K.G. (1993) Pathogenesis of osteoporosis. In: Mundy, G.R. and Martin, T.J., Eds., Pharmacology of Bone, Springer-Verlag, New York, 299-323. doi:10.1007/978-3-642-77991-6_9

[3] Kanis, J.A., Melton, L.J., Christiansen, C., Johnston, C.C. and Khaltaev, N. (1994) The diagnosis of osteoporosis. Journal of Bone and Mineral Research, 9, 1137-1141. doi:10.1002/jbmr.5650090802

[4] Melton, L.J., Chrischilles, E.A., Cooper, C., Lane, A.W. and Riggs, B.L. (1992) Perspective. How many women have osteoporosis? Journal of Bone Minerals Research, 7, 1005-1010. doi:10.1002/jbmr.5650070902

[5] Baheiraei, A., Pocock, N.A., Eisman, J.A., Nguyen, N.D. and Nguyen, T.V. (2005) Bone mineral density, body mass index and cigarette smoking among Iranian women: Implications for prevention. BMC Musculoskeletal Disorders, 6, 1-9.

[6] Bayat, N., Haji, A.Z., Alishiri, G.., Ebadi, A., Hosseini, M. and Laluee, A. (2008) Frequency of osteoporosis and osteopenia in post-menopausal military family's women. JAUMS, 6, 1-6.

[7] Pajoohi, M., Hossein, N.A., Soltani, A., Adibi, H., Maghbuli, G. and Larijani, B. (2003) Changes in bone density and osteoporosis in males 10 to 76 years. Payesh Journal, 3, $39-48$.

[8] Hejazi, J., Kolahi, S. and Mehtadinia, J. (2007) The relation between age, weight, BMD and post menopausal age on BMI in post menopausal women. Journal of Yazd University of Medical Sciences, 16, 68-74.

[9] Momohara, S., Okamoto, H., Yago, T., Furuya, T., Nanke, Y., Kotake, S., et al. (2005) The study of bone mineral density and bone turnover markers in postmenopausal women with active rheumatoid arthritis. Modern Rheumatology, 15, 410-414. doi:10.1007/s10165-005-0435-5

[10] Haugeberg, G., Uhlig, T., Falch, J.A., Halse, J.I., Kvien, T.K. (2000) Bone mineral density and frequency of osteoporosis in female patients with RA, results from 394 patients in Oslo County Rheumatoid Arthritis Register. Arthritis \& Rheumatism, 43, 522-530.

doi:10.1002/1529-0131(200003)43:3<522::AID-ANR7>3 .0.CO;2-Y

[11] Cooper, C., Campion, G. and Melton 3rd, L.J. (1992) Hip fractures in the elderly: A world-wide projection. Osteoporosis International, 2, 285-289. doi:10.1007/BF01623184

[12] World Health Organization (1994) Assessment of fracture risk and its application to screening for postmenopausal osteoporosis. World Health Organization Technical Report Series, No. 843, 1-129.

[13] Gullberg, B., Johnell, O. and Kanis, J.A. (1997) Worldwide projections for hip fracture. Osteoporosis International, 7, 407-413. doi:10.1007/PL00004148

[14] Browner, W.S., Pressman, A.R., Nevitt, M.C. and Cummings, S.R. (1996) Mortality following fractures in older women. The study of osteoporotic fractures. Archives of Internal Medicine, 156, 1521-1525. doi:10.1001/archinte.1996.00440130053006

[15] Larijani, B., Resch, H., Bonjour, J.P, Aghai-Meybodi, H.R. and Mohajery-Tehrani, M.R. (2007) Osteoporosis in Iran, Overview and Management. Iranian Journal of Public Health, a Supplementary Issue on Osteoporosis, 1-13.

[16] Bagheri, P., Haghdoost, A.A., Dortaj, R.E., Halimi, L., Vafaie, Z., Farhangnia, M. and Shayan, L. (2011) Metaanalysis of prevalence of osteoporosis in women. Iranian Journal of Endocrinology and Metabolism, 13, 315-325. 
[17] Derakhshan, S., Salehi, R. and Reshadmanesh, N. (2006) Prevalence of osteoporosis, osteopenia and their related factors in post-menopausal women referring to Kurdistan densitometry center. Scientific Journal of Kurdistan University of Medical Sciences, 11, 59-67.

[18] Mojibian, M., Owlia, M.B., Beiki, B.O. and Kochak, Y.L. (2006) Osteoporosis in postmenopausal women. Iranian Journal of Surgery, 14, 62-70.

[19] Namwongprom, S., Ekmahachai, M., Vilasdechanon, N., Klaipetch, A., Wongboontan, C. and Boonyaprapa, S. (2011) Bone mineral density: Correlation between the lumbar spine, proximal femur and radius in northern Thai women. Journal of the Medical Association of Thailand, 94, 725-731.

[20] Pinheiro, M.M., Reis Neto, E.T., Machado, F.S., Omura, F., Yang, J.H.K., Szejnfeld, I.J. and Szejnfeld, V.L. (2010) Risk factors for osteoporotic fractures and low bone density in pre and postmenopausal women. Revista de Saúde Pública, 44, 479-485. doi:10.1590/S0034-89102010000300011

[21] Meiyanti (2010) Epidemiology of osteoporosis in postmenopausal women aged 47 to 60 years. Universa Medicina, 29, 169-176.

[22] Heidari, Z., Zyaie, S. and Moghassemi, S. (2010) The relationship between BMI and reproductive histories and bone density in postmenopausal women. Arak Medical University Journal, (AMUJ), 13, 53-60.

[23] Jamshidian-Tehrani, M., Kalantari, N., Azadbakht, L., Esmaillzadeh, A., Rajaie, A., Houshiar-rad, A., Golestan, B. and Kamali, Z. (2004) Osteoporosis risk factors in Tehrani women aged 40-60 years. Endocrinology and Metabolism, 6, 139-145.

[24] Zhang, H.C., Kushida, K., Atsumi, K., Kin, K. and Nagano, A. (2002) Effects of age and menopause on spinal bone mineral density in Japanese women: A ten-year prospective study. Calcified Tissue International, 70, 153157. doi:10.1007/s00223-001-1037-7

[25] Jang, S.N., Choi, Y.H., Choi, M.G., Kang, S.H., Jeong, J.Y., Choi, Y.J. and Kim, D.H. (2006) Prevalence and associated factors of osteoporosis among postmenopausal women in Chuncheon: Hallym aging study (HAS). Journal of Preventive Medicine and Public Health, 39, 389396.

[26] Fawzy, T, Muttappallymyalil, J., Sreedharan, J., Ahmed, A., Saeed, A.S.O., Al Ali, M.S. and Al Balsooshi, K.A. (2011) Association between body mass index and bone mineral density in patients referred for dual-energy x-ray absorptiometry scan in Ajman, UAE. Journal of Osteoporosis, 4 Pages.

[27] Elizabeth, J., Dayananda, G., Satyavati, K. and Kumar, P.
(2009) Bone mineral density in healthy south Indian men. Journal of Physiological and Biomedical Sciences, 2, 41-44.

[28] Arimatsu, M., Kitano, T., Kitano, N., Inomoto, T., Shono, M., Futatsuka, M. (2005) Correlation between forearm bone mineral density and body composition in Japanese females aged 18-40 years. Environmental Health and Preventive Medicine, 10, 144-149. doi:10.1007/BF02900807

[29] van der Voort, D.J., Geusens, P.P. and Dinant, G.J. (2001) Risk factors for osteoporosis related to their outcome: Fractures. Osteoporosis International, 12, 630-638. doi:10.1007/s001980170062

[30] Castro, J.P., Joseph, L.A., Shin, J.J., Arora, S.K., Nicasio, J., Shatzkes, J., et al. (2005) Differential effect of obesity on bone mineral density in White, Hispanic and African American women: A cross sectional study. Nutrition \& Metabolism, 2, 9. doi:10.1186/1743-7075-2-9

[31] Maghraoui, A.E., Guerboub, A.A., Mounach, A., Ghozlani, I., Nouijai, A., Ghazi, M., et al. (2007) Body mass index and gynecological factors as determinants of bone mass in healthy Moroccan women. Maturitas, 56, 375-382. doi:10.1016/j.maturitas.2006.10.004

[32] Lewin, S., Gouveia, C.H., Marone, M.M., Wehba, S., Malvestiti, L.F. and Bianco, A.C. (1997) Densidade mineral óssea vertebral e femoral em 724 mulheres brancas brasileiras: Influência da idade e do peso corporal. Revista da Associação Médica Brasileira, 43, 127-136. doi:10.1590/S0104-42301997000200009

[33] Cui, L.H., Choi, J.S., Shin, M.H., Kweon, S.S., Park, K.S., Lee, Y.H., et al. (2008) Prevalence of osteoporosis and reference data for lumbar spine and hip bone mineral density in a Korean population. Journal of Bone and Mineral Metabolism, 26, 609-617. doi:10.1007/s00774-007-0847-8

[34] Tuck S.P., Pearce, M.S., Rawlings, D.J., Birrell, F.N., Parker, L. and Francis, R.M. (2005) Differences in bone mineral density and geometry in men and women: The Newcastle thousand families study at 50 years old. British Journal of Radiology, 78, 493-498. doi: $10.1259 / \mathrm{bjr} / 42380498$

[35] Anburajan, M., Ashok, K.D. and Sapthagirivasan, V. (2011) Evaluation of osteoporosis in Indian women and men using peripheral dual energy $\mathrm{x}$-ray absorptiometry (pDXA). IPCBEE, 5, 470-474.

[36] Lei, S.F., Deng, F.Y., Li, M.-X., Dvornyk, V. and Deng, H.W. (2004) Bone mineral density in elderly Chinese: Effects of age, sex, weight, height, and body mass index. Journal of Bone and Mineral Metabolism, 22, 71-78. doi:10.1007/s00774-003-0452-4 